\title{
Pilomatrixomas in children: Report of 149 cases. A retrospective study at two children's hospitals
}

\author{
Jorge A. Laffargue, M.D. ${ }^{a}$, Paola C. Stefano, M.D. ${ }^{b}$, Jésica L. Vivoda, M.D. ${ }^{a}$, Mónica L. Yarza, M.D., ${ }^{a}$ \\ Ana G. Bellelli, M.D. ${ }^{a}$, María N. Castro, M.D. ${ }^{a}$, Adriana N. Torres Huamani, M.D. ${ }^{b}$, Sebastián N. Apa, M.D. ${ }^{c}$, \\ Daniel Navacchia, M.D. ${ }^{d}$, María Centeno, M.D. ${ }^{e}$, Andrea B. Cervini, M.D. ${ }^{b}$ and Susana A. Grees, M.D. ${ }^{a}$
}

\begin{abstract}
A pilomatrixoma is a benign skin tumor common in children, which develops from the matrix cells of hair follicles.

It presents as a nodule or tumor of approximately $0.5-3 \mathrm{~cm}$ in size, with calcium-like consistency, faceted edges, and blue erythematous overlying skin. Sometimes, the skin may atrophy and look like a blister or even extrude calcium.

Diagnosis is suspected based on the typical clinical presentation and supplementary imaging tests. The definite diagnosis is made according to histological findings. Surgical removal is the treatment of choice.

Here we describe the epidemiological and clinical data, supplementary tests, and surgical techniques in relation to 149 pilomatrixomas resected in 137 patients treated at the Departments of Dermatology of two children's hospitals: Dr. Pedro de Elizalde and Prof. Dr. Juan P. Garrahan.

Key words: pilomatrixoma, adnexal and skin appendage neoplasms, child, surgical procedures.
\end{abstract}

http: / / dx.doi.org/10.5546/ aap.2019.eng.340

To cite: Laffargue JA, Stefano PC, Vivoda JL, Yarza ML, et al. Pilomatrixomas in children: Report of 149 cases. A retrospective study at two children's hospitals. Arch Argent Pediatr 2019;117(5):340-343.

a. Department of Pediatric Dermatology of Hospital de Niños Pedro de Elizalde.

b. Department of Dermatology of Hospital de Pediatría "Prof. Dr. Juan P. Garrahan."

c. Department of Plastic Surgery of Hospital de Pediatría "Prof. Dr. Juan P. Garrahan."

d. Department of Anatomic Pathology of Hospital de Niños Pedro de Elizalde.

e. Department of Anatomic Pathology of Hospital Nacional de Pediatría "Prof. Dr. J. P. Garrahan."

Autonomous City of Buenos Aires, Argentina.

E-mail address:

Jorge Laffargue, M.D.: drjorgealaffargue@gmail.com

Funding: None.

Conflict of interest: None.

Received: 9-16-2018

Accepted: 4-10-2019

\section{INTRODUCTION}

A pilomatrixoma is a benign neoplasm that develops from the matrix cells of hair follicles. Its precise origin is unknown and, although it has been associated with trauma and insect bites, in recent years, a beta-catenine activating mutation has been observed in $75 \%$ of pilomatrixomas, which may be the cause of this entity. Pilomatrixomas are common in children, in the first two decades of life. ${ }^{1}$

Pilomatrixomas typically present as a single, hard nodule or tumor with faceted edges, normal color or blue erythematous overlying skin. They usually develop on the head and neck, although they may also be found on the limbs. They grow slowly and stabilize after a few months or years. In general, they are asymptomatic but may cause pain and swelling. . $^{2,3}$

There are other less frequent clinical presentations. In the anetodermic or pseudobullous variants, pilomatrixomas are covered by atrophic, erythematous skin and telangiectasis. ${ }^{4}$ Rarely, they develop rapidly, resulting in a skin ulcer, and extrude calcium, and these are known as perforating pilomatrixomas. ${ }^{5}$ Another uncommon variant is the giant pilomatrixoma, defined as measuring more than $5 \mathrm{~cm} .{ }^{6}$

Sometimes, patients may have multiple pilomatrixomas. There are familial cases of multiple pilomatrixomas and multiple pilomatrixomas associated with certain syndromes, such as Turner syndrome, constitutional mismatch repair deficiency (CMMR-D), Gardner syndrome, myotonic dystrophy, and Kabuki syndrome. ${ }^{78}$

An ultrasound of the lesion allows to establish the diagnosis in the case of confounding clinical manifestations. A well-delimited image may be observed, with a peripheral hypoechoic halo, isolated microcalcifications or partial calcification, or a completely calcified nodule with intense posterior acoustic shadowing. ${ }^{9}$

Diagnosis is confirmed by histopathology, which shows three types of cells. Peripheral basophilic or basaloid cells, which are immature 
cells of the hair follicle matrix with a large central core and numerous mitoses; transitional cells with acidophilic cytoplasm; and shadow / ghost cells without a core. Other findings include the presence of granulomatous inflammation with multinucleated giant cells, calcium deposits and/ or ossification. ${ }^{2}$

The only treatment possible is surgical removal. Surgery may be delayed in the case of very small, asymptomatic pilomatrixomas that do not cause aesthetic alterations or in young children. $^{2}$

There are different surgical techniques, such as lozenge resection or avulsion. The latter consists in performing an incision in the center of the pilomatrixoma and grabbing it between the thumb and index finger to cause extrusion. The tissue is undermined with Metzenbaum scissors while exerting pressure continuously. This technique reduces surgery duration compared to the lozenge technique and has a lower rate of recurrence and better aesthetic outcomes. ${ }^{10}$ Post-operative complications include wound superinfection, hematoma, suture dehiscence, hypertrophic scar and keloid formation.

The objective of this study was to describe the epidemiological and clinical data, supplementary tests, and treatment of pilomatrixomas resected in two children's hospitals.

\section{DESIGN}

Observational, retrospective and descriptive study.

TABLE 1. Epidemiological and clinical data

\begin{tabular}{ll}
\hline Outcome measure & Total number \\
\hline Sex & Female: 74 \\
& Male: 63 \\
Fge & $\begin{array}{l}\text { From } 9 \text { months to } 18 \text { years old } \\
\text { (mean: } 9.5 \text { years old) }\end{array}$ \\
& 133 classical form \\
Clinical & 11 anetodermic form \\
manifestations & 3 perforating form \\
& 2 giant form \\
& $39,6 \%$, on the upper limbs \\
& $37 \%$, on the head and neck \\
Location & $20 \%$, on the trunk \\
& $3,4 \%$, on the lower limbs \\
\hline
\end{tabular}

\section{MATERIAL AND METHODS}

The medical records of patients diagnosed with pilomatrixoma and seen at the Departments of Dermatology of two children's hospitals (Dr. Pedro de Elizalde and Prof. Dr. Juan P. Garrahan) between March 2011 and March 2016 were reviewed. All patients aged 0-18 years, who underwent surgery at any of the participating facilities and who had a confirmed histopathological diagnosis of pilomatrixoma were included. Patients with pilomatrixomas who were lost to follow-up were excluded.

The following outcome measures were analyzed: age at onset, sex, clinical presentation of pilomatrixoma (classical, papular, nodular, tumor, anetodermic, perforating), location, size, number of lesions in each patient, lesion recurrence, presence of family history of pilomatrixoma, and associated syndromes. Supplementary tests, histological findings, and treatment provided were assessed. The study was approved by the hospitals' Ethics Committees.

\section{RESULTS}

A total of 149 pilomatrixomas were resected in 137 patients (Table 1). Of them, 74 were females (54\%). Patients' age ranged from 9 months to 18 years, with a mean of 9.5 years old.

Most patients had a single pilomatrixoma, but $9(6.57 \%)$ had more than one. No patient had a family history of pilomatrixoma or associated conditions.

From a clinical perspective, most patients $(89 \%)$ had the classical form with the nodular, papular, and tumor variants. Among the rest of the patients, 11 had the anetodermic variant; 3 , the perforating variant; and 2, giant pilomatrixoma (Figures 1, 2, and 3).

Most pilomatrixomas were located on the upper limbs (39.6\%) and the head and neck (37\%), followed by the trunk (20\%); only $3.4 \%$ were on the lower limbs.

An ultrasound was requested for 133 tumors; in 124 of them (93\%), microcalcifications or completely calcified images with posterior acoustic shadowing compatible with pilomatrixoma were observed. All resected pilomatrixomas were assessed by the Department of Anatomic Pathology and showed the typical findings.

Avulsion was done in most cases, while lozenge resection was performed in anetodermic and perforating lesions $(9 \%)$. No post-operative complications were recorded in any case. 
Recurrence was reported in only one patient $(0.6 \%)$.

\section{DISCUSSION}

This was the first retrospective and descriptive study of cases of pilomatrixoma carried out in two children's hospitals in Latin America. It is worth noting that our study included the largest number of cases to date. .11-15 $^{1-1}$

Although the peak of pilomatrixoma occurs in the first two decades of life and then at 5060 years old, in our study, the youngest age at onset was 9 months old and the mean age of participants was 9.5 years. The most frequent location reported in the bibliography is the head and neck; ${ }^{2-8-11}$ in our study, the most common location was the upper limbs. The prevalence of female sex was consistent with that reported in the bibliography. ${ }^{2}$

In our study, classical pilomatrixoma was the most frequent variant, in agreement with what has been reported. ${ }^{2}$ The second most common variant in our study was anetodermicpilomatrixoma. No history of traumatic injuries was found in this variant. The three cases of perforating pilomatrixoma were already present at the time of the office visit and, also, they did not have a history of traumatic injuries. In our study, only two patients had giant pilomatrixoma. None of them had infection in addition.

Although the reported rate of recurrence is $0-6 \%, 11$ in the follow-up of our study only one patient had recurrence to date.

FIGURE 1. Classical pilomatrixoma

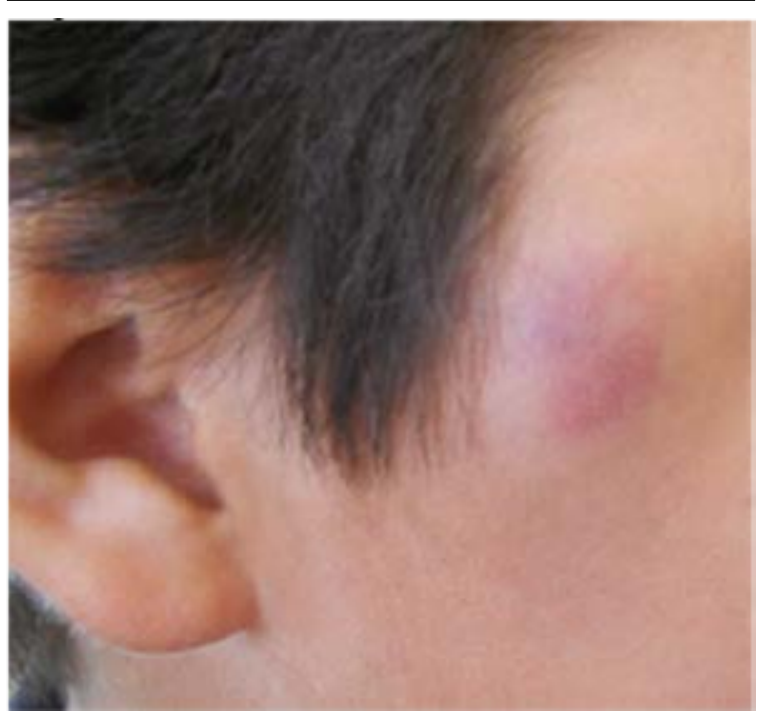

In the latest literature review of pilomatrixomas in children and in association with other abnormalities, $9 \%$ of patients had multiple pilomatrixomas and, of them, $17 \%$ had associated abnormalities. ${ }^{8}$ The most frequent association was with Turner syndrome, followed by CMMR-D, Gardner syndrome, and Steinert muscular dystrophy. Single pilomatrixomas have also been reported with Kabuki syndrome.

In addition, some patients had multiple familial pilomatrixomas not associated with other conditions. The authors emphasize that, although such associations are uncommon and most were diagnosed before the onset of pilomatrixomas, it is recommended to look for them in every patient with single or multiple pilomatrixomas and to provide follow-up over time.

\section{FIGURE 2. Anetodermic or pseudobullouspilomatrixoma}

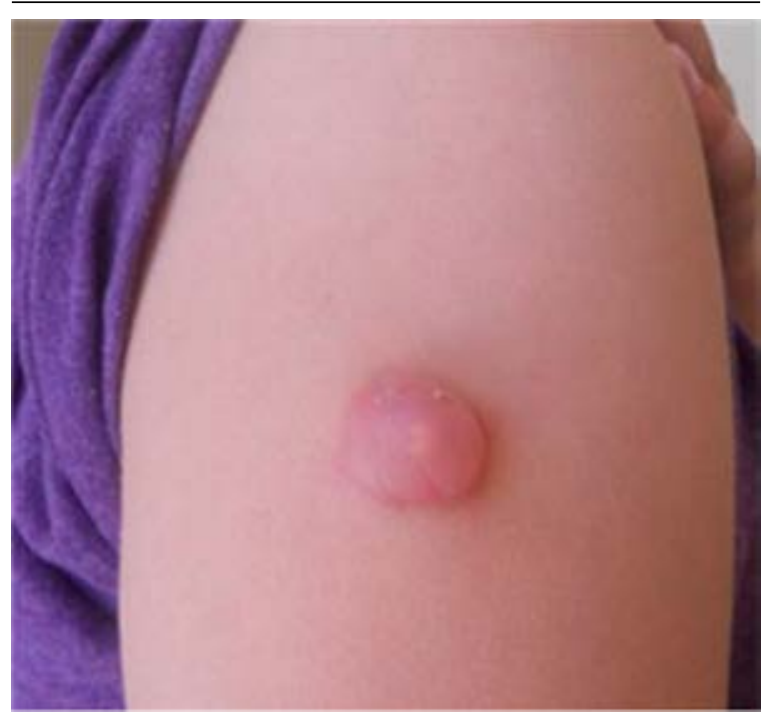

FIgURE 3. Perforating pilomatrixoma

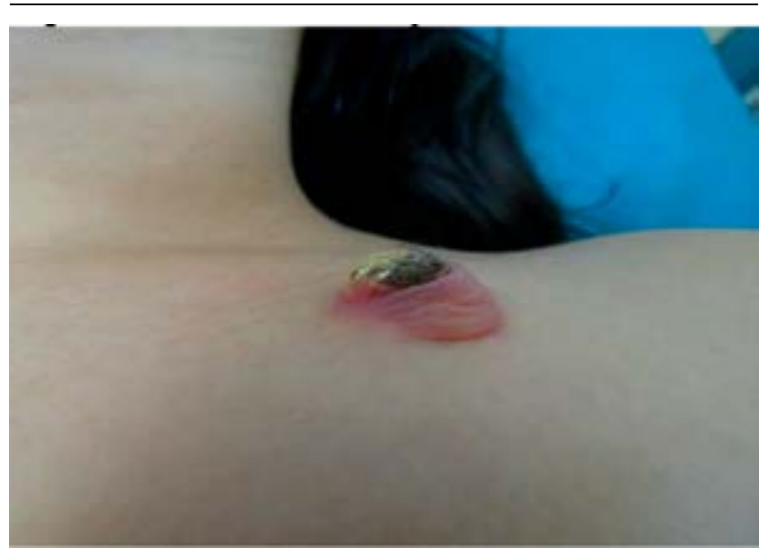


In our study, $6.7 \%$ of patients had more than one pilomatrixoma and none had a family history or associated conditions during the follow-up to date. There are no consensus or suggestions about the duration of follow-up in these patients, but it is important to obtain the complete personal and family history and conduct a complete physical exam to look for the signs of the syndromes associated with pilomatrixomas mentioned above. $^{8}$

It is worth noting that, during tumor resection or avulsion, capillary bleeding is observed that stops once all calcium is removed. This sign has been seen in all resections done in this study and has been designated as bleeding absence. ${ }^{10}$ It is believed that it may be because pilomatrixoma is a superficially located tumor that does not invade subcutaneous cellular tissue.

It is important to know the different presentations and courses of pilomatrixoma in children, which is a common tumor during childhood, and also to consider potential associations. The time for treatment initiation, which is always surgical, will be based on the clinical presentation, size, and rate of tumor growth.

\section{REFERENCES}

1. Hassnein AM, GlanzSM. Beta-catenin expression in benign and malignant pilomatrix neoplasms. Br J Dermatol. 2004; 150(3):511-6.

2. Hoeger PH. Differential diagnosis of skin nodules and cysts. In: Irvine AD, Hoeger PH, Yan AC (eds.). Harper's Textbook of Pediatric Dermatology. $3^{\text {rd }}$ ed. Oxford: Willey Blackwell; 2011.Pages 92.1-6.
3. Grinspan Bozza NO. Signo de la piedra facetada. Diagnóstico del pilomatrixoma. Arch Argent Dermatol. 2007; 57(4):203-5.

4. Concha MR, Farías MM, Abarzúa A, Droppelmann N, et al. Pilomatrixoma: una presentación clínica inusual. Arch Argent Pediatr. 2011; 109(6):e116-8.

5. Ces Costa M, Arias M, Bounsante M, Abeladaño A, et al. Lesión tumoral en muslo. Arch Argent Dermatol. 2007; 58(2):75-7.

6. Stefano P, Apa S, Balancini B. Pilomatrixoma gigante y ulcerado en un niño. Actas Dermasifiliogr. 2013; 104(10): 924-39.

7. García-Arpa M, Vera-Iglesias E, GarcíaRojo M, RomeroAguilera G, et al. Pilomatrixomas múltiples. Med Cutan IberLat Am. 2010; 38(1):48-51.

8. Richet C, Maza A, Dreyfus I, Bourrat E, et al. Childhood pilomatricomas: associated anomalies. PediatrDermatol. 2018; 35(5):548-51.

9. Garioni E, Danesino G, Madonia L. Pilomatricoma: sonographic features. J Ultrasound. 2008; 11(2):76-8.

10. LaffargueJA, MeredizJ, StefanoP. Dermatología quirúrgica pediátrica. In:De Carli E, Jaled M, Coringrato M, Galimberti G, et al. Dermatología quirúrgica y estética. Buenos Aires: Journal; 2014.Pages 105-14.

11. Cigliano B, Baltogiannis N, De Marco M, Faviou E, et al. Pilomatricoma in childhood: a retrospective study from three European paediatric centres. Eur J Pediatr. 2005; 164(11):673-7.

12. Pulvermacker B, Seroussi D, Haddad R, Mitrofanoff M. Pilomatricome ou épithéliome calcifié de Malherbe: a propos d'une série de 89 cas chez l'énfant. Ann Chir Plast Esthet. 2007; 52(1):39-42.

13. Cypel TKS, Vijayasekara V, Somers GR, Zuker RM. Pilomatricoma: Experience of the hospital for sick children. Can J Plast Surg. 2007; 15(3):159-61.

14. Hassan F, Stephens E, Fallon S, Schady D, et al. Characterizing pilomatricomas in children: a single institution experience. J Pediatr Surg. 2013; 48(7):1551-6.

15. KwonD, Grekov K, Krishnan M, Dyleski R. Characteristics of pilomatrixoma in children: a review of 137 patients. Int J Pediatr Otorhinolaryngol. 2014; 78(8):1337-41. 